6-3-2016

\title{
Book Review: Colonial Genocide in Indigenous North America
}

Christopher Davey

University of Bradford

Follow this and additional works at: https://digitalcommons.usf.edu/gsp

\section{Recommended Citation}

Davey, Christopher (2016) "Book Review: Colonial Genocide in Indigenous North America," Genocide Studies and Prevention: An International Journal: Vol. 10: Iss. 1: 107-110.

DOI:

http://dx.doi.org/10.5038/1911-9933.10.1.1387

Available at: https://digitalcommons.usf.edu/gsp/vol10/iss1/10

This Book Review is brought to you for free and open access by the Open Access Journals at Digital Commons @ University of South Florida. It has been accepted for inclusion in Genocide Studies and Prevention: An International Journal by an authorized editor of Digital Commons @ University of South Florida. For more information, please contact digitalcommons@usf.edu. 
Book Review: Colonial Genocide in Indigenous North America

\author{
Christopher Davey \\ University of Bradford \\ Bradford, Yorkshire, United Kingdom
}

Colonial Genocide in Indigenous North America

Andrew Woolford, Jeff Benvenuto, and Alexander Laban Hinton, editors

Durham \& London, Duke University Press, 2014

pp. 360; Cloth: \$94.95, Paperback: \$26.95

Reviewed by Christopher P. Davey

University of Bradford

During September 2012 scholars, activists, legal, and other professionals gathered for a workshop at the University of Manitoba to unpack and retell the legacies of colonialism in North America. ${ }^{1}$ This exercise was conducted under the banner of genocide as a legal, sociological, political, and normative concept. This excellent collection of essays is a product of this 2012 exchange offering a review and syntheses of the conference. This tightly packed anthology not only reviews the contemporary issues of and positions on colonial genocide in North America, but stands as a wedge of discourse around the histories and interpretations of group destruction as part of the civilizing project. This review discusses the audience and aims of the publication, summarizes and connects the chapters, and draws some critical outlines of colonial and wider genocide studies as reflected in the contributors' voices.

Whilst the intended audience extends to scholarly and community-based actors engaged in the work of examining and retelling colonial genocide in North America, the editors establish a case for broader dissemination. Andrew Woolford, Jeff Benvenuto, and Alex Hinton situate their collection in the ongoing national debates about the legacy of civilization not only in Canada and the United States, but also in Australia (4-11). One is drawn to the politics of apologies, thorny discussions on reparations, and the regeneration of activism, challenging perceptions of victimhood and agency. The chief intentions here are the decolonization of genocide studies and frame issues of civilization, colonial legacy, and Indigenous politics using genocide (13). Such sweeping engagement posits this collection as modelled not only for academic shelves, but also, and more normatively, for wider public audiences in North America participating in debates about contemporary Global North privilege, historical assumptions about colonialism, and supposed peaceful assimilation in North America. This normative message is underscored by Theodore Fontaine's foreword. Fontaine, a scholar-survivor of Canada's Indian Residential Schools (IRS), implores a "call to every reader to examine our own awareness, depth of caring, and the integrity with which we apply our own thought processes and our voices to the lives and relationships we build, influence, protect, and empower" (ix). Colonial genocide should then be individually assessed with outcomes informing the "context of the future we must build together." This plea for recognition and reflection falls too often on the unhearing and unwilling to consider the colonial dimensions and legacies of genocide in a domestic context.

The book's organization itself is steered by the contributors' abilities to address the conceptual and theoretical framings of the subject matter and the diversity of the original offering at the 2012 workshop. "Intersections and Trajectories" (Chapters 1-3) identifies levels of colonialism and the latter as a shifting phenomenon; "Erasure and Legibility" (Chapters 4-7) historicize violence and destruction of groups and identities as features of genocide; "Transformations" (Chapters 8-11) frames genocide in a conceptual and etymological process of change; and, "(Re)Imaginings" (Chapters 12-14, including Hinton's conclusion) question and test the label of genocide.

Intersections and trajectories leads out with Woolford's "colonial mesh": a levelled analysis of the institutions and actors party to colonial genocide. The mesh levels include: macro, "dominant

${ }^{1}$ For the programme of the two day workshop see here, $\mathrm{http}$ //www.ncas.rutgers.edu/sites/fasn/files/ColonialGenocide Program.pdf, 
realms of social activity"; meso, regional institutional levels; institutional, noting types of schools; and, micro, regionally adapted interactions of actors and agents (32). Robbie Ethridge develops previously published work on the Mississippian "shatter zone" (49). ${ }^{2}$ Capitalism is framed as radically reshaping the early colonial Mississippian world through slaving and warfare from the mid-sixteenth to the early eighteenth century. Christopher Powell and Julia Peristerakis combine their workshop presentations to present a relational framing of colonial structures and networks, developing Lemkin's specifically defined colonial process of destruction. The production of difference emerges as violent obliteration, referencing Powell's own work. ${ }^{3}$ The destruction "disrupt(s) the social institutions" that "produce and reproduce" social identity for groups $(73,86)$. They cover economic and political aspects, in addition to being book's rare contribution to gender analysis in genocide (81-83).

Erasure and Legibility introduce Benjamin Madley and Gray Whaley's work on the California and Oregon Indian experiences of genocidal assaults. Madley presents, in the traditional narratives of atrocity and ideology, violence as clustered reactionary events with an underlying process of destructive colonization. Dynamics of resistance and asymmetrical warfare are also acknowledged. Whaley develops these above experiences in Oregon drawing attention to "folk imperialism" (131). In contrast to Madley, Whaley expresses unwillingness to broadly cast colonial history as genocide, pointing to the later contribution by Joseph Gone. Whaley further offers a more nuanced view and discursive analysis of the "shift from assimilation to extermination when the colonial population came to believe that extermination was possible, necessary, and justified" (133). Tricia Logan brings valuable insight as a former insider from the Canadian Museum (CMHR). Logan unfolds the contradictions of memory and genocide in the colonial state. Furthermore, she reanimates perceptions of Indigenous agency in history and memory making and problem of impermanence at the CMHR (157). ${ }^{4}$ Dirk Moses' "conceptual blockages" are reflected in Canadian "blind spots" in policy and contemporary memorialization. Jeremy Patzer offers historical discussion of the processes theorized by Woolford, with support from Zygmunt Bauman's sociological approach to institutions and genocide. This critical analysis of reconciliation situates genocide in the Canadian IRS system.

Transformations begins with Margaret Jacobs on child welfare in the context of Patrick Wolfe's "logic of elimination" (191-193). Social construction of the "habits" built around and supporting processes of this logic, again overlapping with the theoretical generalizations made by Woolford. Jeff Benvenuto recasts precolonial history dynamic, complicating supposed victims of colonial genocide as agents and dynamic actors. The problematic nature of Lemkin's national group figuration is discussed, facilitating discussion of the ethnogenesis of the Choctaw, with the rhetorical tool of "cultural rivers" (209) and Schumpeter's "creative destruction," additionally building on Ethridge's shatter zone. Kiera Ladner assesses the political genocide in Canada's civilizing mission by discussing less so the genocide of political groups and more the political processes of group destruction through "regime replacements" and "cultural cancers" (231), focusing on the 1876 Indian Act (236). Colin Samson reveals Innu land claims as instruments of Indian group reconstitution, identification, and legitimacy through Canadian democratic processes. Land dispossession is framed as a "form of genocide" (247), with parallels to contemporary transformations or ethnogenesis as discussed by Benvenuto. Discussion here of amnesia is similar to Jacob's habits where Indian agency becomes subsumed into the civilizing project.

(Re)Imaginings introduces some of the strongest and starkest claims of the book. Joseph Gone highlights definitional issues in genocide studies by outlining "prototypical" and "criterial" approaches (276). Preference is clearly stated for massacres as destruction, critically using the 1948

\footnotetext{
${ }^{2}$ Robbie Ethridge and Sheri M. Shuck-Hall, eds. Mapping the Mississippian Shatter Zone: The Colonial Indian Slave Trade and Regional Instability in the American South, (Lincoln, NE:University of Nebraska Press, 2009).

${ }^{3}$ Christopher Powell, Barbaric Civilization: A Critical Sociology of Genocide (Montreal, Quebec, Canada: McGill-Queen's University Press, 2011).

${ }^{4}$ A fuller critique of the museum's ethos and memorialization process can be found here, A. Dirk Moses, "The Canadian Museum for Human Rights: the 'uniqueness of the Holocaust' and the question of genocide", Journal of Genocide Studies 14, no. 2 (2012): 215-238.
} 
Convention, and disregarding Lemkinian framing of processes of group destruction, also leaning on "everyday discourse" and the slightly ambiguous "earlier generations of genocide scholars" (278). Central for Gone is the problematic impact of broad definitional approaches to genocide and associated discourses on Indigenous mental health, reconciliation, critically evaluating the notion of historical trauma. Tasha Hubbard, expanding on Powell and Peristerakis' relational group identification and construction, turns to the role of biodiversity and buffalo herds in North American genocide. Hubbard claims "the slaughter of buffalo constitutes an act of genocide" (293), and weaves traditional and legalistic interpretations of genocidal processes. The chapter identifies a relational network of agents of genocide: army, "hide hunters" and complicit Indigenous seeking perceived survival (302). David MacDonald also pairs Indigenous perspective using the "Shognosh" label for colonizers and the IRS as an instrumentalization of prohibited Convention acts (removal of children), aiming to present a "binational framework" $(307,319)$. Hinton concludes, highlighting the workshop's points of debate between Indigenous scholars Tamara Starblanket and Gone: respectively between denial of colonial genocide and the incredulous diminishing genocide to "murder without death" (325-326). Critical genocide studies and the pursuit of "genocide studies imaginary" (329) is foregrounded as necessities of continuing this debate in uncovering and analysing the phenomenon of "hidden genocides" (331).

Woolford, Benvenuto, and Hinton have conscientiously collected essays from workshop contributors offering a pioneering combination of critical witness and scholarly analysis. Such a balance is often mis-stepped in attempts to incorporate any voices within a given set of histories of genocide, frequently framing such solely through the lens of the victim/survivor. This is the dividend of such a broad focus on North American colonial genocide. Multiple genocidal processes are considered over a vast temporal framing, incorporating the variability of actors, networks, and institutions. Many of the scholars are themselves speaking from their own Indigenous perspective, narrative or identity, however; such contributions are not limited by an experiential approach, as many maximalist approaches to the Holocaust do. ${ }^{5}$ Conversely, Powell and Peristerakis in an almost throwaway comment underscore the imperative of Indigenous peoples themselves to identify genocide in their social group past (71).

Referencing the works of Ward Churchill and David Stannard as key starting points of colonial genocide studies (both by the editors in the Introduction and by Gone: 9-11, 281-282), debates around colonial genocide are demarcated. Bundled up here though are the deep lying definitional issues within the study of genocide. Many, including Powell, consider such debates to be integral, and part of the emergent nature of genocide, as an "essentially contested concept." Divisions do raise the question of how thoroughly, or even whether or not colonial mass violence is describable or classifiable as genocide. Gone, Whaley and Ethridge offer some provocative and varied positions on this approach. This collection acknowledges these debates and offers a picture of genocide studies as a field with intersecting layers, comprising tensions over definitions, recognitions, and denial. Such can be broadly characterized as between sociological and legalistic perspectives. This simplistic division is perhaps (but not entirely) attributable to Lemkin's own apparent foci across his earlier and later writings. ${ }^{7}$ This specific debate represents the varied trends of using genocide as a rhetorical, political, emotive, and scholarly tool for the gamut of activities from building historical knowledge and social theory, to popular mobilization and even the perpetration of further atrocities or denial.

Wedded to these debates is the utility and structure of the UN Convention's framing of genocide. Indeed as MacDonald and other contributors describe, the Convention itself represents an essential instrument of legal redress. However, can approaches like Gone's emphasizing one part of the Convention (direct mass killing) over another (removing the children of a group), or

\footnotetext{
${ }^{5}$ For further discussion here see Martin Shaw, What is Genocide? (Cambridge, MA:Polity Press, 2007), 37-47; and, again, A. Dirk Moses, “Genocide and the Terror of History," Parallax 17, no. 4 (2011):90-108.

${ }^{6}$ Powel, 59.

${ }^{7}$ Donna Lee-Frieze, “New Approaches to Raphael Lemkin”, Journal of Genocide Research 17, no. 3 (2013): 247-252; and Michael A. McDonnell \& A Dirk Moses, "Raphael Lemkin as historian of genocides in the Americas," Journal of Genocide Research 7, no. 4 (2005): 501-529.
} 
where specific intent, the supposed secret ingredient of any genocide, leave holistic analyses of colonial genocide wanting? ${ }^{8}$ Can such legalistic considerations of what makes a genocidal process offer a thorough picture? One might even consider Logan's contribution here a rebuttal of these types of approaches to genocide that only reproduce blind spots in the post-colonial state as Mahmood Mamdani so clearly outlines in the "bifurcated state." Is the legalistic approach guilty, in a sense, of perpetuating erasure?

Do the more sociological accounts of what is genocide, more recently offered by Martin Shaw and Powell, offer this more holistic approach? Powell and Hubbard's use here of relational conceptions of targeted groups and violent destruction offer a fittingly emergent approach to this phenomenon. This is key as colonial genocide studies is still growing as a sub-field of genocide studies, especially in North America, not to mention the enduring apathy of British memory of colonial genocide. ${ }^{10}$ This collection therefore serves well as a model of further investigation of colonial genocide. As attested to by Fontaine, Powell, and Peristerakis, and the editors some even consider Canada to be a currently colonial state as it continues to engage in or permit forms of obliteration of its indigenous population (viii-ix, 9, 13, 83-85). This kind of analysis is necessary if the questions of memory and reconciliation are to be sufficiently addressed in the face identifying colonial genocide in North America. Woolford, Benvenuto, and Hinton's collection serves to challenge the so-called Pax Americana of peaceful assimilation in a not quite post-colonial North America.

\footnotetext{
${ }^{8}$ Adam Jones, Comprehensive Introduction to Genocide, 2nd ed. (New York, NY: Routledge, 2010), 37-39; see also for more extensive examination, Larry May, Genocide: A Normative Account (New York, NY: Cambridge University Press, 2010), 115-136.

${ }^{9}$ Mahmood Mamdani, Citizen and Subject: Contemporary Africa and the Legacy of Late Colonialism (Princeton, NJ: Princeton University Press, 1996), 19-23.

${ }^{10}$ Tom Lawson, The Last Man: A British Genocide in Tasmania (London: I.B. Tauris, 2014), 2-28.
} 